\section{Castro: $1957-58$}

To the Editors: In May, 1957, I began to serve as a political officer of the U.S. Consulate General in Hong Kong. My first year was spent editing the Survey of the China Mainland Press, which has been the main source of information for the outside world on the People's Republic of China. Copies still go to many governments and universities. The press monitoring unit turned out 25,000-30,000 words a day of translations from newspapers and magazines.

Because I edited them I read themnot every word, but most of them. I noticed one peculiarity that, so $\boldsymbol{f}_{\vec{A}}$ as I am aware, has not been mentioned by any historian. This was the time when Castro was considered in the United States to be a good liberal, trying to overthrow the oppressive government of Batista. Allegations that he was a Communist were vehemently denied. Yet why was it, I wondered, that there were so many articles favorable to Castro in the Chinese press? Did Peking know something that we did not? Anyone interested in this question can look in the SCMP index under Castro or Cuba. I have not done so before writing this letter because (a) I am too busy, and (b) my memory on this point is clear. Castro became prime minister on January 1,1959 . The years $1957-58$ were the ones in which he got such unusual support in the Chinese press. This was before the Sino-Soviet split. China was far from Cuba, far from the Cuban problem.

My point is this, Castro was already known in Moscow to be a dependable agent. He still is-especially in Africa. I find a certain irony in the article recently published in the Russian weekly Ogonyok alleging that Lee Harvey Oswald was a Chinese agent.

Holmes H. Welch

Harvard, Mass
National Endowment for the Humanities Institute on "War and Morality" at the University of Massachusetts/Amherst July 9-July 17, 1979

Core Faculty: Professors Guenter Lewy and William V. O'Brien

A SUMMER INSTITUTE TO PREPARE COLLEGE FACULTY MEMBERS TO TEACH THE MORAL DIMENSIONS OF WAR IN THE TWENTIETH CENTURY.

Topics studied will include the history, characteristics, and enforcement of the law of war, pacifism, nonviolent resistance as an alternative to war, conscientious objection to war in American law, and the special problems of nuclear, limited conventional, and revolutionary/counterinsurgency war. In addition to common readings, participants will be expected to prepare a report on a topic of their choice and to develop a course outline.

College teachers of undergraduate courses in a variety of disciplines, including the humanistic social sciences, 'will be selected from among faculty nominated by their institutions. All participants must have completed their professional training by March 9, 1979, i.e., they may not be enrolled currently in a graduate program, but they need not necessarily have the Ph.D. or other advanced degrees to qualify.
Preference will be given to faculty members from smaller institutions. Participants will receive a stipend of $\$ 2,000$ and travel expenses. They and their home institutions will have to commit themselves to offer a course on "War and Morality" or to enrich an existing course or program within eighteen months of the end of the institute. Each institution nominating a successful candidate must contribute $\$ 100$ to the cost of the institute.

Faculty members interested in attending the institute and college administrators wishing to submit nominations should contact Professor Guenter Lewy, Department of Political Science, University of Massachusetts, Amherst, Massachusetts 01003 . The deadline for the receipt of nominations is March 9,1979 . Awards will be announced on March 30, 1979. Selected participants will have ten days to accept or decline.

\section{WORLDVEW Statement of Purpose}

The purpose of Worldview is to place public policies, particularly in international affairs, under close ethical scrutiny. The Council on Religion and International Affairs, which sponsors the journal, was founded in 1914 by religious and civic leaders brought together by Andrew Camegie. It was mandated to work toward ending the barbarity of war, to encourage international cooperation, and to promote justice. The Council is independent and nonsectarian. Worldview is an important part of the Council's wide-ranging program in pursuit of these goals.

Worldview is open to diverse viewpoints and encourages dialogue and debate on issues of public significance. It is edited in the belief that large political questions cannot be considered adequately apart from ethical and religious reflection. The opinions expressed in Worldview do not necessarily reflect the positions of the Council. Through Worldview the Council aims to advance the national and international exchange with out which our understanding will be dangerously limited.

Philip A. Johnson, Publisher

Editorial Board:

Hans Morgenthau, Chairman

William J. Barnds

Eugene B. Borowitz

Noel J. Brown.

Jorge Dominguez

James Finn

J. Bryan Hehir

Donald F. McHenry (on leave)

Paul Ramsey

Seymour Siegel

Paul Sigmund

Kenneth W. Thompson

Howard Wriggins (on leave)

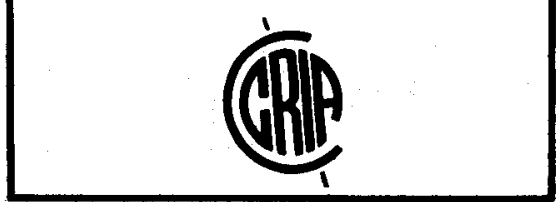

